\title{
Skoliose kan avdekkes i forbindelse med helseundersøkelsen
}

Barn og unge som trenger behandling av sin skoliose, bør bli oppdaget og henvist på et tidlig stadium.

\section{Marit Fure}

Spesialfysioterapeut

Ortopedisk klinikk, Oslo universitetssykehus

\section{Minni Bains}

Spesialfysioterapeut

Avdeling ortose og korsett, Sophies Minde

Helsekontroll

Helseopplysning

\section{Hovedbudskap}

Helsedirektoratet har kommet med nye retningslinjer for helseunders $\varnothing$ kelsen som skal gjennomføres på første og åttende trinn. Helsesykepleierne blir bedt om å unders $\varnothing$ ke kroppsholdningen hos barnet eller ungdommen, men mange er usikre på hva de faktisk skal se etter. Med opplæring av helsesykepleiere i hva som er vanlige kjennetegn, ønsker vi å bidra til at skoliose avdekkes tidlig, slik at barn og unge med skoliose kan henvises til riktig instans.

Ifølge dagens retningslinjer fra Helsedirektoratet skal det som en del av helseunders $\varnothing$ kelsen på første og åttende trinn gjennomføres en holdningsunders $\varnothing$ kelse (1). 
Det presiseres at dette ikke er en skoliosescreening. Likevel er holdningsunders $\varnothing$ kelsen en gyllen anledning til å observere elevenes rygger og eventuelt avdekke skoliose.

\section{Hva er skoliose?}

Skoliose er definert som en krumning av ryggraden på over 10 grader. Det finnes ulike typer skoliose, og vi deler disse inn i hovedgruppene idiopatisk skoliose, nevromuskulær skoliose, syndromskoliose og kongenitt skoliose. Inndeling etter alder for debut av deformiteten er også vanlig.

Idiopatisk skoliose oppstår uten kjent årsak, hos ellers friske barn og ungdommer. Dette er den største gruppen og utgjør cirka 85 prosent av alle tilfeller med skoliose. Idiopatisk skoliose over 10 grader forekommer hos cirka 2-3 prosent av befolkningen.

\section{«Det vanligste er at det skjer en utvikling av deformiteten i perioder med såkalt vekstspurt.»}

De fleste med skoliose lever helt fint med det, uten behov for spesiell oppfølgning. Cirka 10 prosent trenger konservativ behandling i form av korsettbehandling og/eller trening, mens $0,1-0,3$ prosent trenger operativ behandling av deformiteten (2).

Idiopatisk skoliose kan utvikle seg i barne- eller ungdomsårene. Det vanligste er at det skjer en utvikling av deformiteten i perioder med såkalt vekstspurt. Vekstspurt er rask høydevekst i begynnelsen av puberteten. Størst risiko er det i puberteten, i alderen mellom 11 og 14 år.

Etter fullført vekst er det mye lavere risiko for utvikling av skoliose, men det er en risiko for at en allerede påbegynt skoliose fortsetter å utvikle seg om kurven er over 30 grader etter fullført vekst (3). 
Tilstanden rammer oftere jenter enn gutter. Idiopatisk skoliose gir vanligvis ingen symptomer og blir veldig ofte oppdaget ved en tilfeldighet av foreldre. Noen få rapporterer om ryggsmerter, men sterke smerter er uvanlig.

\section{Hvordan oppdager man skoliose?}

I en holdningsunders $\varnothing$ kelse observeres eleven forfra og bakfra. Ved en skoliose kan man se at

- skulderen kan være høy på den ene siden

- skulderbladet kan stikke mer ut på den ene siden

- hoftekammen kan være høyere på den ene siden

- bekkenet kan være forskjøvet til den ene siden

- ribben kan stikke ut bak på midtryggen/korsryggen

- ribben kan stikke ut på fremsiden på den ene siden

- midjen ser ujevn ut (avstand mellom arm og midje)

- overkroppen er forskjøvet mer mot den ene siden

- hodet ikke er sentrert over bekkenet

Ved mistanke om skoliose ber man barnet eller ungdommen bøye seg frem (Adam's forward bend test) (4). Ved skoliose vil man se en forhøyning på den ene siden, som kalles en gibbus.

\section{Når og til hvem bør man henvise?}

Alle barn under ti år med påvist skoliose skal henvises til Rikshospitalet ved Oslo universitetssykehus (OUS), da den nasjonale behandlingstjenesten for denne pasientgruppen er lokalisert her.

Barn og ungdom over ti år som fortsatt er i vekst, og med kurve målt til 20 grader eller mer, skal henvises til fastlege. Fastlegen skal ved behov henvise videre til nærmeste ortopediske avdeling. Der vurderes det om det skal henvises videre til spesialisthelsetjenesten og de sykehusene som behandler skoliose: St. Olavs hospital, Haukeland universitetssjukehus eller Rikshospitalet, OUS. 


\section{Behandling avhenger av typen skoliose}

Hvilke tiltak som iverksettes, avhenger av typen

skoliose, størrelsen, utviklingen av kurven og

gjenværende vekst hos barnet/ungdommen.

Oppfølging gjøres i mange tilfeller ved kun å

observere. Barnet/ungdommen kommer til jevnlige

kontroller hvor det tas røntgen av ryggen for å følge

med på kurvens utvikling.

\section{«Målet med korsettbehandling er å stoppe, eller eventuelt å redusere, kurveprogresjon $\mathrm{i}$ puberteten.»}

En korrigerende ryggortose brukes på overkroppen etter anbefaling fra ortoped og ortopediingeniør. Målet med korsettbehandling er å stoppe, eller eventuelt å redusere, kurveprogresjon i puberteten.

Operasjon kan være nødvendig ved stor skjevhet i ryggen, for å forhindre at skjevheten utvikler seg ytterligere.

\section{Barn med skoliose bør være aktive}

Ifølge Rikshospitalet er barn og unge med skoliose anbefalt å delta i idrett, lek og aktiviteter. Studier viser at personer med skoliose som trener regelmessig, har høyere selvtillit, bedre psykisk helse og bedre selvbilde (5).

\section{«Ingen aktiviteter er uegnede for barn og ungdommer med skoliose.»}

Derfor anbefales barn og unge med skoliose fysisk aktivitet, spesielt siden deltakelsen ikke ser ut til å påvirke forekomsten eller graden av skoliose (6). Vi oppfordrer derfor barn til å delta i gym på skolen. Ingen aktiviteter er uegnede for barn og ungdommer med skoliose. 


\section{Målet er tidlig oppdagelse}

Ved å unders $\varnothing$ ke barn og unges kroppsholdning kan man oppdage skoliose på et tidlig stadium og sikre at riktige tiltak blir iverksatt. Om kurvene oppdages etter skjelettmodning, vil mulighetene for å starte med konservativ behandling reduseres.

Målet er derfor at barn og unge som trenger behandling av sin skoliose, blir oppdaget og henvist på et tidlig stadium.

\section{Referanser}

1. Helsedirektoratet. Helsestasjons- og skolehelsetjenesten. 5.2 Helseunders $\varnothing$ kelse og helsesamtale. Oslo: Helsedirektoratet; 2019.

Tilgjengelig fra:

https://www.helsedirektoratet.no/retningslinjer/helsest asjons-og-skolehelsetjenesten/skolehelsetjenesten520-ar/helseundersokelse-og-helsesamtale\#veiing-ogmaling-skolehelsetjenesten-bor-male-vekt-og-hoydepa-barn-og-unge (nedlastet 26.04.2021).

2. Negrini S, Donzelli S, Aulisa AG, Czaprowski D, Schreiber S, de Mauroy JC, et al. 2016 SOSORT guidelines: orthopaedic and rehabilitation treatment of idiopathic scoliosis during growth. Scoliosis and Spinal Disorders. 2018;13(1):1-48.

3. Dimeglio A, Canavese F, Charles YP. Growth and adolescent idiopathic scoliosis: when and how much? Journal of Pediatric Orthopaedics. 2011;31(1 Suppl):S28-S36.

4. Scoliosis Research Society. Diagnosis \& screening of scoliosis. Tilgjengelig fra: https://www.srs.org/patients-and-families/commonquestions-and-glossary/frequently-askedquestions/diagnosis--screening-of-scoliosis (nedlastet 26.04.2021). 
5. Fällström K, Cochran T, Nachemson A. Longterm effects on personality development in patients with adolescent idiopathic scoliosis. Influence of type of treatment. Spine. 1986;11(7):756-8.

6. Kenanidis E, Potoupnis ME, Papavasiliou KA, Sayegh FE, Kapetanos GA. Adolescent idiopathic scoliosis and exercising: is there truly a liaison? Spine. 2008;33(20):2160-5. 